\title{
ELECTRONIC COMMERCE AND TURKISH PATTERNS OF ONLINE FOOD DELIVERY SYSTEM
}

\author{
Mehmet ÇAVUŞOĞLU *+, mcavusoglu@comu.edu.tr
}

Accompanied by the progress of information and communication technologies, the Internet and e-commerce, which are in increasing use in almost all business sectors, paved the way for a new virtual organization model based on computer data. This development compels numerous classical business sectors to do business in internet medium. With this study, it is intended that this new-found but fast growing virtual business of "Online Food Delivery" companies of Turkey will be examined and sector's growth potentialities dissected. In the first chapter of the study, virtual organizations and electronic commerce have been defined. In the second chapter, the operation system of virtual food delivery organizations put forward and existing virtual firms of online food delivery of Turkey listed. In the final chapter, how to further spread and developed the web sites of Turkish online food delivery and problems of sector are summarized.

Keywords: Virtual Organization, Electronic Commerce, Online Food Delivery.

JEL Codes: M15, M31, D83, L81

\section{Elektronik ticaret ve Türkiye'deki online yiyecek dağıtım işletme modelleri}

Bilgi ve iletişim teknolojilerindeki gelişmeler, birçok sektörde İnternet ve e-ticaret destekli sanal organizasyon modellerinin gelişmesine neden olmuştur. Bu gelişmeler, klasik sistemde iş yapan birçok sektörü, İnternet ortamında da iş yapmaya zorlamaktadır. Bu çalışmada, yeni bir iş fikri olarak ortaya çıkmış ve büyüme potansiyeli yüksek “Online Yiyecek Dağıtım" işletmelerinin Türkiye'deki gelişimi incelenmiştir. Çalışmanın ilk bölümde, sanal organizasyon ve elektronik ticaret açıklanmıştır. İkinci bölümde, “Online Yiyecek Dağıtım” organizasyonu açılanmış ve Türkiye'de faaliyet gösteren online yiyecek dağıtım işletmeleri listelenmiştir. Son bölümde ise Türkiye'de faaliyet gösteren online yiyecek dağıtım işletmelerinin yaygınlaşması ve gelişimi için yapılması gerekenler ve sektörün sorunları özetlenmiştir.

Anahtar Kelimeler: Sanal Organizasyon, E-ticaret, Online Yiyecek Dağıtımı.

\footnotetext{
* Çanakkale Onsekiz Mart Üniversitesi, Gökçeada Meslek Yüksekokulu

+ This article is utilized and derived from "Electronic Commerce And Turkish Patterns of Virtual

Organisations of Food And Drinks" article, which is presented in Int. Tourism Biennial 2007
} 
Çavuşoğlu $M$.

\section{INTRODUCTION}

Recent progress of information technologies and global competition, force business firms to adopt a virtual networking model within the framework of virtual organizations. The virtual organization models present the opportunities of surviving in the harsh global competition and developing new businesses and new management strategies. The internet economy, which is also known as the new economic system, has helped the creation and diffusion of e-commrece all over the world, which is based on internet perse and moves everywhere on earth through computer networks.

Today, it is imperative for business concerns to keep abreast of technological breakthroughs and employ them in order to be able to compete and survive. Technology helps corporations to cut costs and to diversify themselves against their competitors. Moreover, the conservative approaches render firms that resist changes disadvantageous, through their organizational structures. The information flows to and from the suppliers as well as dealers through electronic networks help fast delivery of products, constant delivery of goods to the customers, elimination of uncertainties on the production planning, whereby reducing the costs to a great extent.

The purpose of this study was to define the electronic commerce and virtual organisations of online food delivery. Initially virtual organizations and electronic commerce have been defined. Then we define the operation styles, advantages and the problems of virtual online food delivery organizations. In the final chapter, we summarized how to further spread and developed the business sector of Turkish virtual organizations of online food delivery.

\section{VIRTUAL ORGANIZATIONS}

Virtual organization is a semi stable network of organizations and/or individuals in a constantly changing environment creating a temporary structure from the members of the network and/or other organizations to meet opportunities of the market. This temporary structure is disbanded when goals are achieved. Every member of the network delivers its/his core competencies for this new structure, they are geographically dispersed and therefore use information and communication technologies as a main communication device (Duoba, 2007).

The virtual organization is a dynamic alliance between organizations that bring in complementary competencies and resources and that are collectively available to each other, with the objective of delivering a product or service to the market as a collective. Virtual organization's refers to a new organizational form characterized by a temporary or permanent collection of geographically dispersed individuals, groups or organization departments not belonging to the 
same organization or entire organizations, that are dependent on electronic communication for carrying out their production process (Sieber, Griese, 1998).

Virtual organisation is defined as a temporary coalition of reconfigurable, independent, networked, geographically dispersed organizations including high level trust and competencies that collaborate and share their resources and competencies in order to fulfill the customer request (Nami \& Tavangarian, 2011)

In virtual organizations,customer satisfaction is augmented by shortening the period of getting back to customers through new-technology feedbacks, by taking great leaps forward in uninterrupted communications among relevant firms and in time and motion studies for the firms in the processes of production and marketing (Kartal, 2007).

Cooperating managements under the roof of a virtual organization adopt a common target. This target is the fast production and presentation of goods and services demanded by the markets to the customers in concerted efforts. Virtual organization is created by combination of autonomous and independent business concerns and/or phases. In achieving the ultimate objective, it is necessary that the activities of different units are carried out same time same place. Besides, the participating units may exhibit different roles and suppliers, customers and even competitors may combine their supplementary sources and abilities. Developments of information technologies, as well as changing global competition terms constitutes the driving force of virtual organization structures (Kurşunmaden, 2007).

Virtual organisations are composed of a number of semi-independent autonomous entities (representing different individuals, departments and organisations) each of which has a range of problem solving capabilities and resources at their disposal. These entities co-exist and sometimes compete with one another in a ubiquitous virtual marketplace (Norman, 2004).

\section{DEFINITION OF ELECTRONIC COMMERCE (E-COMMERCE)}

Electronic Business is the use of the Internet and other related information technologies for organizational communication and coordination and the management of the firm. By replacing manual and paper based procedures with electronic alternatives and by using information routes in new and active ways, electronic business can speed up the processes of ordering, delivering and paying for goods and services as well as reducing a companies operating and inventory costs (Maner, 2007). Electronic commerce working systems is shown in Figure 1.

Electronic commerce (e-commerce) is sharing business information, maintaining business relationships and conducting business transactions by means of

IUYD'2012 / 3(1) 
Çavuşoğlu $M$.

telecommunication networks (Zwass, 1996). It describes the way in which transactions take place over telecommunication networks. In the long history of humanity, few innovations have encompassed as much potential as e-commerce does, in part due to the global natural of its technology, its low cost, its opportunity to reach hundreds of millions of people and its interactive nature (Ma, 2010).

Electronic commerce is the method by which the order is placed or received, not the payment or channel of delivery, which determines whether the transaction is an electronic commerce transaction (Vuylsteke, 2011). Electronic commerce is based on the followings: (Dong, 2010)

$>$ From a communications perspective, E-commerce is the delivery of information, products/services, or payments via telephone lines, computer networks, or any other means.

> From a business process perspective, E-commerce is the application of technology toward the automation of business transactions and workflow.

$>$ From a service perspective, E-commerce is a tool that addresses the desire of firms, consumers and management to cut service costs while improving the quality of goods and increasing the speed of service delivery.

$>$ From an online perspective, E-commerce provides the capability of buying and selling products and information on the Internet and other online services.

Since the invent of Internet and electronic commerce alot of habits have changed in human life. Now a days from clothes to electronic gadgets, from books to toys, every thing can be purchased online. Now even food can be ordered online while sitting at homes/offices with the convenience, only provided by the Internet. Online food ordering system is an advantage offered by the Internet to the restaurant industry. The system provides convenience to both restaurateurs and their customers. (Dhamija, 2008). In parallel with the developments in electronic commerce, there are significant changes in food delivery systems. In the following chapter, we explained "Online Food Delivery" system, the advantages and the problems. 


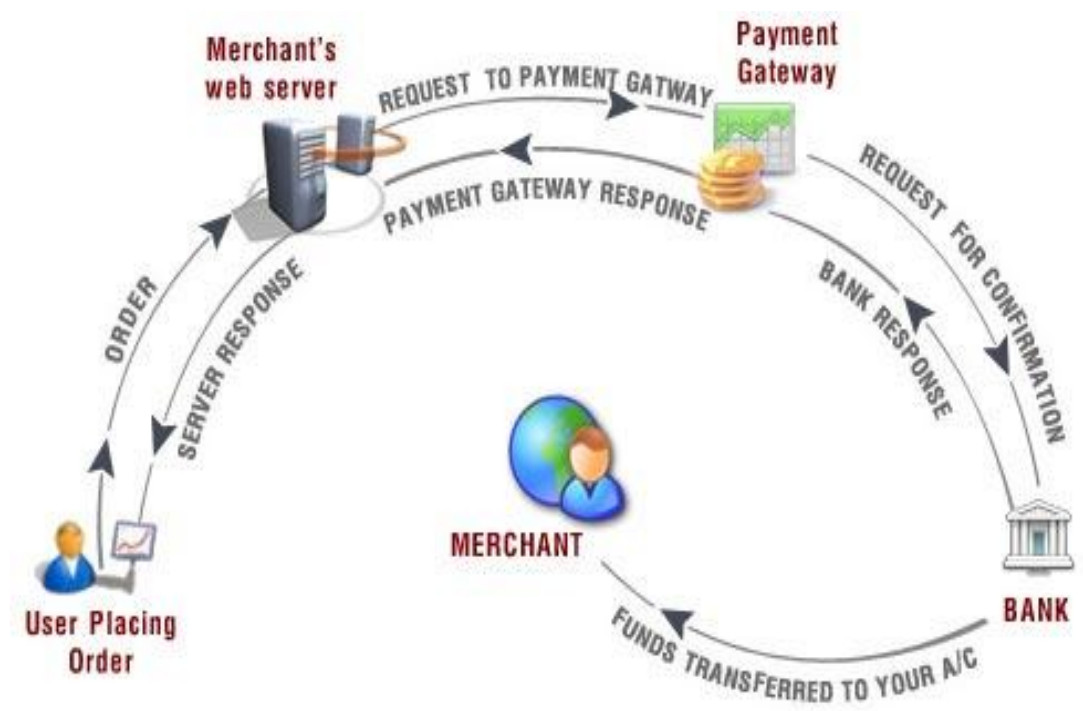

\section{Figure 1. Electronic Commerce Working Systems}

Kaynak:www.swipecanada.com, 2012

\section{DEFINITION OF ONLINE FOOD DELIVERY}

The nutrition patterns of the contemporary man differ from the past's in a substantial way. Because of the transformation of technology, urbanization, integration of women into work-life, rat race of working, endless journeys, living alone, human beings spare less time for eating, thus changing their nutritive habits. Fast food consuming is on the rise, making the expressions of "nibbling" and "eating while standing" daily life commonalties. Fast food or readily available food systems are based on servicing more consumers in shorter time periods with which food is prepared in standard ways and served to customers. Not only did this system help resolve time constraints of man who spends the day away from home and also addressed to their palates. In our country, the term "fast food" means both eating while standing and readily available food systems. The most common fast food types in Turkey are pretzel, toast, "doner", pancake with spicy meat filling, pita bread, hamburgers, cold-cut sandwiches, pizzas, French-fries, fried chicken pieces, fish-in- bread, baked-potatoes, lamb intestines grilled on spit, cokes, tea, coffee etc (www.afiyetle.com, 2012).

The entrepreneurs following the evolution of internet technologies and ecommerce present an ever-changing trading model to the economic life. In recent years, Turkish entrepreneurs have brought a new business model which may jolt the food sectors. These virtual or on line businesses are in fact quite common in 


\section{Çavuşoğlu M.}

developed countries. It is becoming also common in our country, adding a new flavor and a new momentum to the packaged food conceptualization. In developing countries, e-commerce is opening up new vistas for businesses through an effective and cheaper distribution channel, enabling them to develop new production processes, to enter into new markets without having to make heavy investments and present cheaper quality goods in a faster way and to develop strategic cooperation and joint ventures.

Online food delivery is your instant relief from communication barriers between restaurant and the person on the other end of the phone. Customers call and attempt to order an ethnic dish only to find out the person who is taking your order does not understand you or you just do not understand them. No matter how many times you try to express your desire to order a particular dish, you cannot seem to get it across to the person talking your order. Online restaurant food ordering for delivery eliminates the hassles of communication barriers (http://eat24hours.com, 2012).

Online food delivery businesses come together under a national roof and have an organization of strategic collaboration in a franchise system. In this system, the online food delivery businesses assume an intermediary role and give an image of a single organization to the clientele. The parties to the online food delivery business system are presented in the Figure 2.

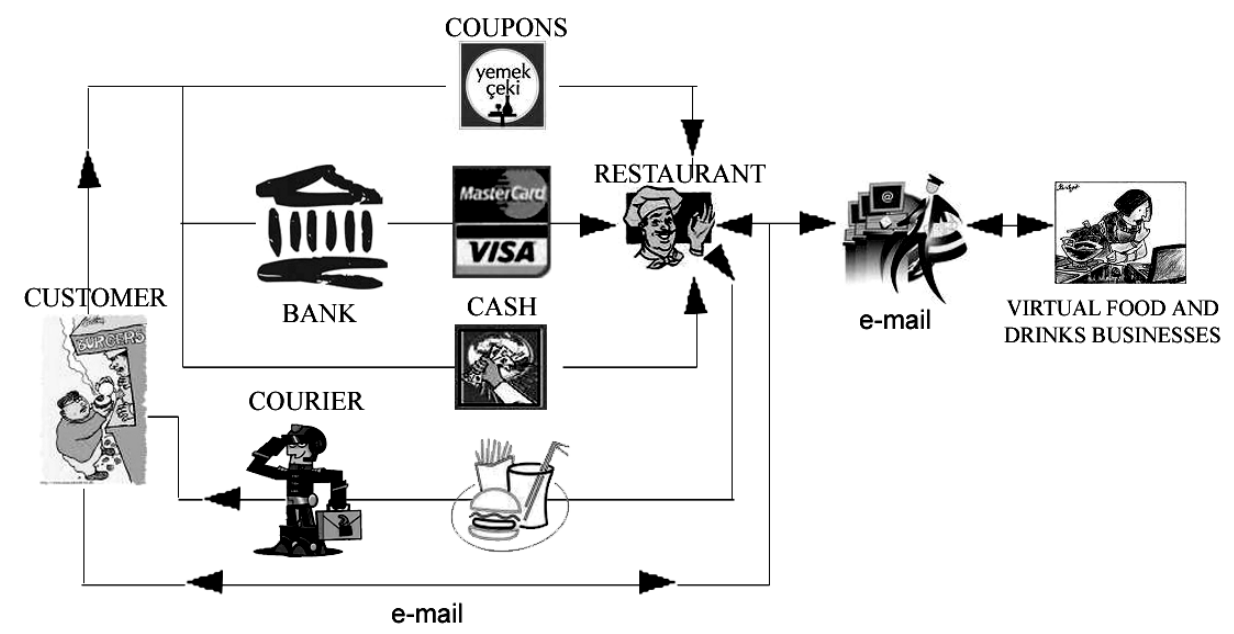

Figure 2: The Parties To The Online Food Delivery Businesses And Their Operation Systems

\subsection{The Differences Between Classical And Online, Food Delivery Businesses}

From the management, information and marketing points of view, there are discernible differences between classical and online food delivery businesses. These differences are outlined in Table 1. 
Table 1. The Comparison Of Classical And Online Food Delivery Businesses

\begin{tabular}{|l|l|l|}
\hline \multicolumn{1}{|c|}{ SERVICES } & \multicolumn{1}{c|}{$\begin{array}{c}\text { CLASSICAL } \\
\text { Food Delivery Businesses }\end{array}$} & \multicolumn{1}{c|}{$\begin{array}{c}\text { ONLINE } \\
\text { Food Delivery } \\
\text { Businesses }\end{array}$} \\
\hline $\begin{array}{l}\text { Getting to know the food } \\
\text { processor }\end{array}$ & Vis-à-vis or advertisements & $\begin{array}{l}\text { Internet } \\
\text { advertisements }\end{array}$ \\
\hline Order method & Telephone & Electronic messages \\
\hline Information about prices & Vis-à-vis or advertisements & Electronic messages \\
\hline $\begin{array}{l}\text { Sales and promotion } \\
\text { campaigns }\end{array}$ & None & Yes \\
\hline $\begin{array}{l}\text { Are there standards for food } \\
\text { delivery system? }\end{array}$ & Sometimes & Yes \\
\hline Service periods & Limited & Round the clock \\
\hline Delivery periods & Unknown & Very fast \\
\hline Fake order ratio & High & Very low \\
\hline $\begin{array}{l}\text { Customer } \\
\text { system }\end{array}$ & None & Yes \\
\hline $\begin{array}{l}\text { Order } \\
\text { sanctions }\end{array}$ & None & $\begin{array}{l}\text { Cash, credit cards, coupons } \\
\text { coupons }\end{array}$ \\
\hline \begin{tabular}{l} 
Payment choices \\
\hline
\end{tabular} & cards, \\
\hline
\end{tabular}

\subsection{The Advantages Presented By Online Food Delivery Businesses}

There are multiple advantages of online food delivery sector to the national economy. These can be summarized as follows:

- Creating a new and varied working system for businesses, e-commerce has brought a new vision to the relationships between the sellers and the buyers. The online food delivery businesses have thus gotten into the picture.

- Online food delivery businesses have speeded up purchase and sales and related activities, brought to the production international standards, contributed to effective publicity and set the stage for reliable trading through internet and thus traceable orders.

- Bringing national and international fast food businesses together, it has created opportunities for the local businesses to acquire new production methods, to provide the customers as well as suppliers modern business images and to work in a customer-focused way. 
Çavuşoğlu $M$.

- Unnecessary expenses have been cut for maximization of profit, which in turn reduced the costs of inventories, advertisements, marketing and transportation and helped raise the productivity.

- Online food delivery web sites encourage certain production standard and presentation of the food to the clientele in a pre-ordained quality to the member restaurants.

- Seven days, 24 hours services became available to the clientele.

- Online food firms are flexible in placing your advanced order.

- You don't waste your time on the phone or waiting in queues.

- Customers were given the opportunity to choose and order food among a varying degree of food firms.

- Competition induced quality conscience.

- Easy ordering systems.

- Enabling the restaurateurs to easily identify the frequent customers and their preferred orders (Dhamija, 2008).

\section{THE ONLINE FOOD DELIVERY BUSINESSES IN TURKEY}

Turkish local food delivery businesses work in general on phone call system, hardly giving a reliable marketing posture. With the classical food delivery businesses, it is essential that an employee is employed to take the fast food orders. This employee is constantly on the phone, takes orders and instructs other employees that the order is prepared for delivery. So-packaged product is sent to the customer through the service of distribution personnel, if any, if not, by any of the employees. In this system, the customer's address is generally verbally conveyed to the distribution people and thus delivery problems are experienced.

The classical food delivery businesses may experience numerous problems in their relationships with their customers. Some of these problems from the customers perspective can be summarized as follows:

- Which fast food firms in the area I live?

- What their phone numbers are?

- What is the range of fast foods and outside servicing of them?

- Are there menus? Any reduced fast foods among them?

- How long will it take before I get the fast food? 


\section{Online Food Delivery System}

- How can I pay for the fast food? Is credit card payment available at the door? Are coupons available? Will the delivery-person give me the change of the money I give him?

Also bugging considerations and questions might be in relation to the contents and cooking ways of foods I give order for. And I might be anxious if the order taking guy has got me right and thus bring me the right food?

The online food delivery businesses have firstly changed their order taking models, transforming it into written formats through electronic mail systems and thus developed substantive solutions to above problems in Turkey. Later on, metropolitan fast food producers who showed desires to become members of a system convened under the roof of a single web site. The web site hosted the following information and choices: pretty well detailed food types, menu choices and economic food menus, payment possibilities with credit cards at the door, cash and payments with coupons-opportunity goods, order calculation sections, trading baskets, delivery day and hours, membership facilities for fast food businesses as well as customers. In recent years, online food delivery web sites has become widely used in Turkey.

Turkish online food delivery businesses are summarized below according to their virtual identities, their missions and visions, their operating systems and principles. Table 2 provides information on the comparison made between Turkish online food delivery businesses.

\section{a) www.yemeksepeti.com}

Yemeksepeti.com is the first of its kind in Turkey and the most developed now. Yemeksepeti.com was inaugurated in 2000 and was aimed at speeding up and streamlining the packaged food concepts. The mission was described at food ordering through internet. Supported by full technological features, this facility operates in an interactive medium with almost zero-fault ratio, making deliveries of orders to the customers in a shortest possible time in a faultless possible manner. Yemeksepeti.com provides services between customers and fast food firms in return for a certain commission. The URL has also English version (www.yemeksepeti.com, 2007).

\section{b) www.neleryesek.com}

Neleryesek.com has begun operating in Mediterranean Region of Turkey from October 2005. It provides to customers the Mediterranean Restaurants updated menus and food (dish) pictures on an online virtual facility. Free membership is provided to customers who may also earn points in their credit card payments. These points can also be used in their food orders in this URL. Customer orders 
Çavuşoğlu $M$.

are delivered in 10 to 45 minutes, which can be covered by desired payment methods at the door collaborates with restaurants through a membership system "Neleryesek.com" claims to end the food choice problem in the Mediterranean Region (www.sektoreldizin.com, 2012).

c) www. istelezzet.com

İstelezzet.com is a website from which you can order from a hundred of business, that serve in restaurant, cafe, delicatessen, butcher, greengrocer and patisseria sectors, without paying extra fee and seven days and twenty four hours. It is not necessary for you to define your credit card information to our system as you pay when you get your order. Carrying out analyses and researches, istelezzet.com stated the needs and deficiencies of the sector, blended it with its experience and set up its own system. istelezzet.com set it as a mission to have this interagency work properly and to work for the advantage of the sectoral development by carrying out analyses, researches and studies of marketing and education for the business and the members. It can serve for individual and institutional users (www.istelezzet.com, 2012).

\section{d) www.neyiyelim.com}

Neyiyelim.com has been set up e-commerce website for restaurants and gives managament of them to the businesses since 2006. In this way, restaurants attain constancy of customers, raise their profit and have the necessary time for advertising their new products. While reducing the selling costs, supply costs, customer services costs and the time loss of the customer services, our website is also able to reach to the mew markets 24 hours a day. Neyiyelim.com aims to raise the customer satisfaction of existing customers and appeal to the new customers (onlineyemek.com, 2012).

\section{e) www.yessek.com}

Yessek.com is an online food ordering website which has Turkey's largest service area. Main goal of the firm is to fulfill both our institutional members and ordering members' needs fast and in quality. Yessek.com works according to the principles below: (www.yessek.com, 2012)

$>$ Customer can see all the companies that can serve with just one click.

$>$ Customer can order in any restaurant by observing deeply.

$>$ Customer can order by observing and camparing the price of the product that they want.

$>$ Yessek.com eliminate all the possible misunderstandings between the seller and the customer by recording the order and the necessary information about it. 
Yessek.com solve the problem of what I will eat in the morning or in the afternoon everyday for our customers who are in business world.

\section{f) www.uniyemek.com}

Uniyemek.com is the first online food delivery web site which gives service expecially to the university students.

Table 2. The Service Comparison Of Turkish Food Delivery Web Sites

\begin{tabular}{|l|c|c|c|c|c|}
\hline \multicolumn{1}{|c|}{$\begin{array}{c}\text { Food Delivery Web } \\
\text { Site }\end{array}$} & $\begin{array}{c}\text { Multi } \\
\text { Language }\end{array}$ & $\begin{array}{c}\text { Payment } \\
\text { System }\end{array}$ & $\begin{array}{c}7 / 24 \text { Online } \\
\text { Assistance }\end{array}$ & $\begin{array}{c}\text { Call } \\
\text { Centre }\end{array}$ & $\begin{array}{c}\text { Activity } \\
\text { Area }\end{array}$ \\
\hline www.yemeksepeti.com & Yes & $\begin{array}{c}\text { At The } \\
\text { Door/Form } \\
\text { Site }\end{array}$ & $\begin{array}{c}\text { Yes/Robotic } \\
\text { System }\end{array}$ & Yes & Local \\
\hline www.neleryesek.com & No & $\begin{array}{c}\text { At The } \\
\text { Door }\end{array}$ & Yes & Yes & Local \\
\hline www. istelezzet.com & No & $\begin{array}{c}\text { At The } \\
\text { Door }\end{array}$ & Yes & Yes & Local \\
\hline www.neyiyelim.com & Yes & $\begin{array}{c}\text { At The } \\
\text { Door }\end{array}$ & Yes & No & Local \\
\hline www.yessek.com & Yes & $\begin{array}{c}\text { At The } \\
\text { Door }\end{array}$ & No & No & Local \\
\hline www.uniyemek.com & No & $\begin{array}{c}\text { At The } \\
\text { Door }\end{array}$ & Yes & Yes & Local \\
\hline
\end{tabular}

\section{SOME INTERNATIONAL ONLINE FOOD DELIVERY BUSINESSES}

Some international online food delivery businesses are summarized below according to their virtual identities, their missions and visions, their operating systems and principles. Table 3 provides information on the comparison made between International online food delivery businesses.

\section{a) www.just-eat.com}

Just-Eat opened its virtual doors in 2001. Founded in Denmark by a group of friends with a serious case of the munchies, Just-Eat have gone on to become the undisputed online champ of European takeaway, with local flavours in eight countries. Just-Eat now have over 15000 restaurants in our family bucket and receive an extra large portion of $3.5 \mathrm{~m}$ visits a month, serving over 100000 meals a day. (http://www.just-eat.co.uk, 2012) 
Çavuşoğlu $M$.

b) www.orderit.ca

Orderit.ca has been serving online food in Canada. Individual vendors in Orderit.ca, may set their own delivery area. Delivery area of site is based on distance between the address for delivery and the vendor. For a list of available restaurants in site, simply enter the delivery address (including postal code) the list will be generated for the customer. (www.orderit.ca, 2012)

c) www.seamless.com

Seamless.com is the best way to order food for delivery and pickup from over 7,500 restaurants and 40+ cuisine types. Seamless.com is the nation's largest online and mobile food ordering company and has made ordering food fun and easy for more than one million members and many of the world's largest companies. On Seamless you can browse menus, view ratings, read reviews and discover great new food delivery restaurants in your neighborhood. Seamless offers full menus, ratings, reviews and exclusive discounts from an extensive network of restaurants in New York, Washington DC, Boston, Chicago, San Francisco, Los Angeles, Philadelphia, London and other US cities (Seamless, 2012)

\section{d) www.meal2go.com}

Meal2Go is the UK's first on-line food ordering website, with 1000s of restaurants and takeaways to choose from. With variety of takeaway types, from Chinese to Caribbean and Italian to Indian. Meal2go.com is the most well known online food ordering website in UK (www.meal2go.com, 2012).

e) http://foodrunner.co.nz/

FoodRunner is New Zelland, Auckland's premier food home delivery express. Customers can order by sending a text message, calling our tollfree number or via the internet to the FoodRunner website. They can pay by cash, eftpos, credit card or Restaurant Association Gift Voucher (foodrunner.co.nz, 2012). 
Table 3. The Service Comparison Of International Food Delivery Web Sites

\begin{tabular}{|c|c|c|c|c|c|c|}
\hline $\begin{array}{l}\text { Food Delivery } \\
\text { Web Site }\end{array}$ & $\begin{array}{c}\text { Post } \\
\text { Code } \\
\text { System }\end{array}$ & $\begin{array}{c}\text { Multi } \\
\text { Languag } \\
\text { e }\end{array}$ & $\begin{array}{l}\text { Payment } \\
\text { System }\end{array}$ & $\begin{array}{c}7 / 24 \\
\text { Online } \\
\text { Assistanc } \\
\text { e }\end{array}$ & $\begin{array}{l}\text { Call } \\
\text { Centr } \\
\text { e }\end{array}$ & $\begin{array}{c}\text { Firm } \\
\text { Activity } \\
\text { Area }\end{array}$ \\
\hline $\begin{array}{l}\text { www.just- } \\
\text { eat.com }\end{array}$ & Yes & No & $\begin{array}{c}\text { At The } \\
\text { Door/From } \\
\text { Site }\end{array}$ & Yes & Yes & International \\
\hline www.orderit.ca & Yes & No & $\begin{array}{l}\text { At The } \\
\text { Door }\end{array}$ & No & Yes & Local \\
\hline $\begin{array}{l}\text { www.seamless.co } \\
\text { m }\end{array}$ & Yes & No & $\begin{array}{c}\text { At The } \\
\text { Door/From } \\
\text { Site }\end{array}$ & $\mathrm{No}$ & Yes & International \\
\hline $\begin{array}{l}\text { www.meal2go.co } \\
\text { m }\end{array}$ & Yes & No & $\begin{array}{c}\text { At The } \\
\text { Door/From } \\
\text { Site }\end{array}$ & Yes & Yes & International \\
\hline foodrunner.co.nz & $\mathrm{No}$ & $\mathrm{No}$ & $\begin{array}{c}\text { At The } \\
\text { Door/From } \\
\text { Site }\end{array}$ & $\mathrm{No}$ & Yes & Local \\
\hline
\end{tabular}

\section{THE DIFFERENCES BETWEEN INTERNATIONAL AND TURKISH WEB SITES}

There are discernible differences between Turkish and international food delivery businesses. These differences are outlined below:

- International online food delivery web sites are generally designed in one language. Turkish online food delivery web sites are generally designed in multi language.

- The customers must give their postal codes for membership to site. This postal code helps to online food delivery web site for finding the adres easily. Turkish online food delivery web sites just wants customer's adres information in membership procedure.

- International online food delivery web sites generally use online payment systems in their site. Turkish online food delivery web sites generally use payment at the door system.

- International online food delivery web sites generally use call centre system for communication with their customers. Turkish online food delivery web sites generally use 7/24 Online assistance system. 
Çavuşoğlu $M$.

- International online food delivery web sites generally active worldwide, Turkish online food delivery web sites are local firms.

\section{CONCLUSION}

Accompanied by the rapid progress of information technologies cause changes in the working systems. This development enforces numerous classical business sectors to do business invirtual medium. Particularly the intense work pace of big cities, long working hours, long transportation intervals, increase in the number of women working, the urban dwellers spending their daily lives more in their working places than in their homes and their growing habit of using internet for multi-purposes have adversely affected their home cooking and eating at home habits, creating fast food culture. With this study, it is intended that this newfound but fast growing "Online Food Delivery Companies" of Turkey examined and sector's growth potentialities investigated.

Finally, we summarized the problems of online food delivery firms in Turkey, which is on the way to become a full member of the European Union and Turkish fast food sectors and its likely contributions of sustainable tourism developments and solution proposals.

\section{The Problems Of Online Food Delivery Businesses:}

- Lack of proper introduction of the online food delivery businesses to the clientele narrows the business potentials.

- Inadequacy of home computer diffusion because of inefficient technological internet infrastructure confines the customer potential to a limited width.

- Fast food habits are confined to metropolises and university circles and thus diffusion to non-university hosting towns are still out of the reach of the virtual food systems.

- Free membership is a double-edged sword. Sometimes the verification of customer

personal data is not made or confirmed properly and false orders may appear not infrequently.

- Lack of food hygiene and proper production standards of a great deal of Turkish food producing firms is frightening away some prospective customers. For this reason, particularly in tourism spots, tourists prefer such international names as Mc.Donalds, Pizza Hut etc. 
Online Food Delivery System

- The delivery guy makes many stops to deliver his products, so sometimes you may get cold foods (Summer, 2012).

\section{Remarks And Proposals On What Can Be Done By The Online Food Delivery Businesses:}

- Eligibility of only those food firms with food standards certificates.

- Fast internet infrastructures and diffuse of them in university hosting cities.

- National diffusion may be conditioned on franchising system.

- Inclusion of gigantic international food delivery firms into membership systems.

- Limited but standard friendly food delivery products and inclusion of names into the membership lists.

- Publicity and introduction of online food delivery sites through newspaper, TV ads.

\section{REFERENCES}

Dong, S. \& Zou, L. (2010). Study On Impact Of E-Commerce Development On Enterprises Operation And Management, Retrived From The Web: 7 March 2012, URL: http://ieeexplore.ieee.org/stamp/stamp.jsp?tp=\&arnumber=5628673

Duoba, K. (2007). Relationship Betweenb Virtual Organization And Entrepreneurship. Retrived From The Web: 20 February 2007, URL: www.ktc.lt/modules/getfile.php?id=28

Dhamija, S. (2008). Online Food Ordering: The Internet Advantage. Retrived From The Web: 24 March 2012, URL: http://www.articlesbase.com/food-andbeverage-articles/online-food-ordering-the-internet-advantage-679401.html

Electronic Commerce Working Systems, (2012). Retrived From The Web: 12 March 2012, URL: http://www.swipecanada.com/ecommerce.php

Fast Food. (2012). Retrived From The Web: 28 February 2012, URL: http://www.afiyetle.com/makale.php?mid=1491\&d=fast-+food

Istelezzet.com. (2012). Retrived From The Web: 12 March 2012, URL: http://www.istelezzet.com/Content.aspx?CatID=4

Kartal, H. (2007). Teknoloji ve Sanal Organizasyonlar, Retrived From The Web: 20 February 2007,

URL: 
Çavuşoğlu $M$.

http://www.makalem.com/Search/ArticleDetails.asp?bWhere=true\&nARTICL E_id $=3808$

Kurşunmaden, F. (2007). Sanal Organizasyonlarda İnsan Kaynakları Yönetimi, Retrived From The Web: 20 February 2007, URL: http://www.selcukkariyer.com/makaleler.asp?ID=6

Ma, Z. (2010). Mapping The Intellectual Structure Of Electronic Commerce Research: 1997-2006, Int. J. Electronic Business, Vol. 8, No. 1, 2010, Retrived From The Web: 1 March 2012, URL: http://inderscience.metapress.com/content/u804275754x26504/fulltext.pdf

Maner, M . (2007). Electronic Business. Retrived From The Web: 20 February 2007, URL: http://pigseye.kennesaw.edu/ mam7384/Final\%20Project.html

Nami, M.Reza \& Tavangarian, D. (2011). Virtual Organization: A New Approach in IT, Seventh International Conference on Computer and Information Technology, p:94, Retrived From The Web, 28 February 2012, URL: http://ieeexplore.ieee.org/stamp/stamp.jsp?tp=\&arnumber=4385063

NelerYesek.com. (2012). Neleryesek.com, Retrived From The Web, 1 March 2012, URL: http://www.sektoreldizin.com/yiyecek-icecek/neleryesek-com.htm

Neyiyelim.com. (2012). About Us, Retrived From The Web: 12 March 2012, URL:http://onlineyemek.com/index.php?route=information/information\&info rmation_id $=4$

Norman T., Alun P., Stuart C., Nicholas J., Michael L. \& Viet D., Thuc N., Vikas D., Jianhua S., W.Alex G., Nick F. (2004). Agent-Based Formation Of Virtual Organisations, Knowledge-Based Systems, Volume 17, Issues 2-4, May 2004, Pages 103-111, Retrived From The Web, 28 February 2012, URL: http://www.sciencedirect.com/science/article/pii/S0950705104000061

Opportunties For New FoodRunner Merchant, (2012). Retrived From The Web: 26 March 2012, URL: http://foodrunner.co.nz/index.php?option=com content\&view $=$ article\&id $=48 \&$ Itemid $=56$

Seamless, (2012). About Us, Retrived From The Web, 26 March 2012, URL: http://www.seamless.com/about-us/

Sieber, P \& Griese, J. (1998). Organizational Virtualness, Retrived From The Web, 28 February 2012, URL: citeseerx.ist.psu.edu/viewdoc/download?doi=10.1.1.83

Summer Sharon, (2012). Merits And Advantages Of Online Food Delivery, Retrived From The Web: 24 March 2012, URL: http://www.foolsource.net/archives/4389 
Online Food Delivery System

Vuylsteke, A \& Simon F., (2011). The Impact Of Industry Stracture On ECommerce Initiatives In The Developing World: Two Case Studies From Trinidad And Tobago, First Monday, Volume 16, Number 9 - 5 September 2011, Retrived From The Web: 28 February 2012. URL: http://firstmonday.org/htbin/cgiwrap/bin/ojs/index.php/fm/article/view/3377/ 3046

What Is Online Food Delivery?, (2012). Retrived From The Web: 1 March 2012, URL: http://blog.eat24hours.com/what-is-online-food-delivery

What's The Story, (2012). Retrived From The Web: 26 March 2012. URL: http://www.just-eat.co.uk/contact

What Is Orderit.ca? (2012). Retrived From The Web: 26 March 2012. URL: http://www.meal2go.com/cont/index.php?cont=faq

What Is Meal2Go, (2012). Retrived From The Web: 26 March 2012. URL: http://www.orderit.ca/AboutUs

Yemeksepeti.com. (2007). About Us, Retrived From The Web, 20 February 2007, URL: http://www.yemeksepeti.com/aboutus.asp

Yessek.com. (2012). About Us, RetrivedFrom The Web: 12 March 2012, URL: http://www.yessek.com/default.asp?git=biz

Zwass, V. (1996). Electronic Commerce: Structures and Issues, International Journal of Electronic Commerce, Volume 1, Number 1, Fall, 1996, pp. 3 - 23., Retrived From The Web: 12 March 2012, URL: citeseerx.ist.psu.edu/viewdoc/download?doi=10.1.1.133.9834.. 
